\title{
Distribution of cave-dwelling pseudoscorpions (Arachnida) in Brazil
}

\author{
Diego Monteiro von Schimonsky $\ddagger$, Maria Elina Bichuette§ \\ ‡ Faculdade de Filosofia, Ciências e Letras de Riberião Preto - FFCLRP - USP, Ribeirão Preto, Brazil \\ § Universidade Federal de São Carlos, São Carlos, Brazil
}

Corresponding author: Diego Monteiro von Schimonsky (dmvschimonsky@gmail.com)

Received: 06 Oct 2018 | Published: 09 Oct 2018

Citation: von Schimonsky D, Bichuette M (2018) Distribution of cave-dwelling pseudoscorpions (Arachnida) in Brazil. ARPHA Conference Abstracts 1: e30378. https://doi.org/10.3897/aca.1.e30378

\begin{abstract}
Pseudoscorpions are one of the most diverse of the smaller arachnid orders but there is relatively little information about the distribution of these tiny animals, especially in Neotropical caves. Here we map the distribution of the Pseudoscorpiones in Brazilian caves with record of 12 families and 22 genera, total 313 caves from 13 states. Among them, two families (Atemnidae and Geogarypidae) with three genera (Brazilatemnus Muchmore, 1975, Paratemnoides Harvey, 1991 and Geogarypus Chamberlin, 1930) are recorded for the first time in cave habitat as well as other seven genera previously unknown for Brazilian caves (Olpiolum Beier, 1931, Pachyolpium Beier 1931, Tyrannochthonius Chamberlin, 1929, Lagynochthonius Beier, 1951, Neocheiridium Beier 1932, Ideoblothrus Balzan, 1892 and Heterolophus Tömösváry, 1884) but these genera are from families already recorded in this habitat, and have their distributional ranges expanded for all other previously recorded genera. We present these data in maps, considering the biogeographical provinces. For the genus Spelaeochernes Mahnert, 2001, we re-evaluate its Schiner-Racovitza status and propose the troglobite status. Finally, we discuss the ranges of the pseudoscorpion families/genera for Brazilian caves (Suppl. material 1).
\end{abstract}

\section{Keywords}

biogeographical provinces, cave fauna, Neotropical, Pseudoscorpiones 


\section{Presenting author}

Maria Elina Bichuette

\section{Presented at}

$24^{\text {th }}$ International Conference on Subterranean Biology

\section{Funding program}

Coordenação de Aperfeiçoamento de Pessoal de Nível Superior - CAPES, Conselho Nacional de Desenvolvimento Científico e Tecnológico - CNPq and Fundação de Amparo à Pesquisa do Estado de São Paulo - Fapesp

\section{Hosting institution}

Universidade de Aveiro, Aveiro - Portugal

\section{Supplementary material}

Suppl. material 1: Distribution of cave-dwelling pseudoscorpions (Arachnida) in Brazil doi

Authors: Diego Monteiro von Schimonsky, Maria Elina Bichuette

Data type: distribution, images, maps

Filename: VonSchimonsky_Bichuette_24ICSB_Distribution_Brazilian_Pseudoscorpion.pdf -

Download file (1.70 MB) 